\title{
Comparison of Wet-Digestion and Dry-Ashing Methods for Total Elemental Analysis of Biochar
}

\author{
AKIO ENDERS AND JOHANNES LEHMANN \\ Department of Crop and Soil Sciences, Cornell University, Ithaca NY 14853
}

\begin{abstract}
Total elemental analyses of biochars presents challenges during digestion because of biochars' high chemical recalcitrance and widely varied composition. Three biochars were chosen with contrasting properties: corn stover pyrolyzed at $300{ }^{\circ} \mathrm{C}$, oak wood at $600{ }^{\circ} \mathrm{C}$, and poultry manure with sawdust at $600^{\circ} \mathrm{C}$. Recovery of phosphorus $(P)$, potassium $(\mathrm{K})$, sulfur $(\mathrm{S})$, calcium $(\mathrm{Ca})$, magnesium $(\mathrm{Mg})$, and zinc $(\mathrm{Zn})$ from poultry manure biochar was 10 to 100 times less with published wet- or dry-digestion methods than when using improved methods. The published dry-digestion method returned significantly $(\mathrm{P}<0.05)$ more sodium $(\mathrm{Na})$, suggesting contamination from borosilicate glassware. A modified dry-ashing (MDA) method was the most precise method, demonstrating a relative standard deviation within $3.7 \%$ of the most precise method for recovery of $P, K, S, C a, M g$, and Zn from both corn and oak biochars. The MDA method is comparatively safe and effective for preparing biochar for elemental analysis.
\end{abstract}

Keywords Agricultural waste, carbon, testing methodology

\section{Introduction}

Pyrolysis carbonizes biomass to produce a highly recalcitrant material, termed biochar, that possesses unique agronomic properties (Lehmann 2007). Quantification of the elemental contents of these biochars is of importance as they may influence soil health and fertility (Chan and Xu 2009). On the one hand, plant nutrients contained in the biochar may improve soil fertility; on the other hand, toxic elements may decrease plant growth and pose a health hazard to humans. Total elemental contents will then also be critical to quantify losses during pyrolysis.

Biochar presents a challenge for total elemental analysis. It is likely that the recalcitrant nature of biochar (Cheng et al. 2008; Kuzyakov et al. 2009) requires more aggressive digestion methods than typically used for plant materials and entirely different methods than soil where mainly silicates are dissolved. The term biochar refers to a wide range of possible materials. Composition of the original biomass largely determines elemental content, whereas pyrolysis temperature confers significant changes to the molecular and functional group chemistry (Amonette and Joseph 2009).

Inductively coupled plasma-atomic emission spectroscopy (ICP-AES) is capable of determining the content of plant macro- and micronutrients as well as heavy metals in a single sample (Huang and Schulte 1985). Complete dissolution of the sample into a liquid matrix prior to analysis is necessary to ensure that the total content is analyzed (Huang and Schulte 1985; Ali, Zoltai, and Radford 1988). There has been considerable

Received 3 August 2010; accepted 17 July 2011.

Address correspondence to Johannes Lehmann, Department of Crop and Soil Sciences, Cornell University, Ithaca, NY 14853. E-mail: CL273@cornell.edu 
debate over the effect of residual carbon (C) on ICP-AES analyses. The high temperature of the excitation plasma has been found to effectively decompose $\mathrm{C}$ species (Havlin and Soltanpour 1980). However, there is concern that residual organic matter affects analysis by altering nebulization efficiency or by increasing the optical background (Wasilewska et al. 2002).

Numerous wet-digestion and dry-ashing methods have been proposed to prepare plant samples for elemental analysis (Jones 2001). Dry-ashing methods are comparatively simpler and safer than wet-digestion methods but may introduce error due to volatilization, especially for phosphorous (P), potassium (K), sulfur (S), arsenic (As), selenium (Se), and mercury (Hg) (Ali, Zoltai, and Radford 1988). In addition, dry ashing may be problematic with pyrolytic organic materials as they may resist thermal decomposition at temperatures of about $550{ }^{\circ} \mathrm{C}$, which are commonly used for analytical ashing. Dynamic thermal analyses of black $\mathrm{C}$ have demonstrated that combustion often occurs above $500{ }^{\circ} \mathrm{C}$ (Hsieh 2007 ; Tartarelli et al. 1987).

Wet-digestion methods are preferable because of the speed with which tissue is processed (Oliva, Raitio, and Mingorance 2003). However, wet digestion of biochars may in some cases be incomplete because of their recalcitrant nature. In fact, several methods to physically isolate chars use chemical oxidation that leaves pyrogenic carbon (C) behind (Masiello 2004; Hammes et al. 2007). These techniques utilize strong inorganic acids and in some cases hydrogen peroxide $\left(\mathrm{H}_{2} \mathrm{O}_{2}\right)$ to decompose the samples. Perchloric acid $\left(\mathrm{HClO}_{4}\right)$ was commonly used some time ago because of its strongly oxidizing ability but has largely been avoided because of handling issues, its capacity to react violently with organic compounds, and the possibility of explosion when dry. Additionally, the use of $\mathrm{HClO}_{4}$ requires special ventilation equipment (Havlin and Soltanpour 1980; Huang and Schulte 1985). Nitric acid $\left(\mathrm{HNO}_{3}\right)$ in combination with hydrogen peroxide $\left(\mathrm{H}_{2} \mathrm{O}_{2}\right)$ is an effective substitute for $\mathrm{HClO}_{4}$, with the benefit of increased safety (Huang and Schulte 1985) and unanimously high solubility of nitrate salts (Dean 1999). Sulfuric acid is useful for digestions because of its high boiling point of $335.5^{\circ} \mathrm{C}$ (Dean 1999), but its use is limited by the low solubility of certain sulfate salts, particularly calcium sulfate $\left(\mathrm{CaSO}_{4}\right)$ (Jones 2001).

Therefore, the purpose of this article is to identify safe, reliable, and accessible digestion methods that best capture elemental contents of biochars. Specific objectives were to (i) compare existing methods for plant tissue decomposition for their efficacy; (ii) develop new protocols based on available methods to improve decomposition; and (iii) compare the efficiency of methods across different biochar properties.

\section{Materials and Methods}

Three biochars were chosen representing a range of properties: (1) low temperature, cellulose-dominated corn stover biochar produced at $300{ }^{\circ} \mathrm{C}$ (Corn300); (2) hightemperature, lignin-dominated oak wood biochar at $600{ }^{\circ} \mathrm{C}$ (Oak600); and (3) hightemperature, high-ash content poultry manure mixed with sawdust at $600{ }^{\circ} \mathrm{C}$ (Poultry600). All biochars were produced by a slow pyrolysis process (Daisy Reactor, Best Energies, Inc., Cashton, Wisc., USA). Approximately $3 \mathrm{~kg}$ of feedstock were manually placed into a main chamber, which was thoroughly purged with nitrogen gas $\left(\mathrm{N}_{2}\right)$ (with the mixer running). The predried material ( $<10 \%$ moisture) was isothermically charred for 80-90 min, including rising temperature to the target with a few degrees per minute and holding at a final temperature for 15-20 min. After completion of the pyrolysis, the furnace was turned off and the main chamber was allowed to cool before scooping the biochar under $\mathrm{N}_{2}$ purge 
Table 1

Chemical and physical properties of the studied biochars

\begin{tabular}{lcccccc}
\hline Feedstock & $\begin{array}{c}\text { Pyrolysis temperature } \\
\left({ }^{\circ} \mathrm{C}\right)\end{array}$ & $\begin{array}{c}\text { Carbon } \\
\left(\mathrm{mg} \mathrm{g}^{-1}\right)\end{array}$ & $\begin{array}{c}\text { Nitrogen } \\
\left(\mathrm{mg} \mathrm{g}^{-1}\right)\end{array}$ & $\mathrm{O} / \mathrm{C}$ & $\mathrm{H} / \mathrm{C}$ & $\begin{array}{c}\text { Ash }^{a} \\
(\%)\end{array}$ \\
\hline Corn & 300 & 587.8 & 11.6 & 0.46 & 0.073 & 9.0 \\
Oak & 600 & 875.9 & 1.7 & 0.10 & 0.030 & 1.3 \\
Poultry & 600 & 235.8 & 9.4 & 0.83 & 0.008 & 55.8 \\
\hline
\end{tabular}

${ }^{a}$ According to ASTM D1762-84 Chemical Analysis of Wood Charcoal.

to reduce rapid oxidation and auto-ignition, leading to a more homogeneous product. The properties of the biochars are shown in Table 1. Homogenized apple leaves (ApCk) were provided by Cornell Nutrient Analysis Laboratory as a standard material for quality control and were routinely decomposed prior to ICP analysis according to the U.S. Environmental Protection Agency (USEPA) 3052 Microwave-Assisted Acid Digestion of Siliceous and Organically Based Matrices.

Five digestion methods were examined for elemental recovery: (1) published wetdigestion (PWD) and (2) published dry-ashing (PDA) methods for plant tissue, (3) modified wet-digestion (MWD) and (4) modified dry-ashing (MDA) methods to accommodate biochar recalcitrance, and (5) perchloric and nitric acid wet digestion (PNW). The nitric acid wet-digestion method for plant tissue proposed by Campbell and Plank (1998) was utilized as PWD because of its simplicity and speed. It is analogous to numerous planttissue digestion methods with the exception that it does not require the digest to reach a clear colorless endpoint prior to spectrometric quantification. In contrast, the dry-ashing method proposed by Campbell and Plank (1998) requires that ash reach a colorless state prior to solubilization. The PDA therefore represents the colorless endpoint achieved by thermal decomposition alone. The MWD was undertaken to validate the clear colorless endpoint and demonstrate what was necessary to achieve the same with biochar. The MDA is a hybrid method that utilizes thermal oxidation to achieve the bulk of sample decomposition and chemical oxidation to reach completion. The PNW was used to provide a basis for comparison as it is often used in plant analysis.

Each of the three biochars was processed in triplicate for each of the five methods. Triplicate ApCk standards and blanks were included in every execution of digestion or ashing.

\section{Sample Preparation}

All labware was washed with laboratory detergent, soaked in $10 \%$ hydrochloric acid solution overnight, thoroughly rinsed in deionized water, and then dried at $85{ }^{\circ} \mathrm{C}$. Tall form factor, 25 - by $150-\mathrm{mm}$ borosilicate glass tubes were used as both digestion and ashing vessels (\#9825-25, Corning Life Sciences, Corning, N.Y.). Boron contamination from borosilicate glassware has been documented but was accepted for these analyses in favor of using commonly available labware. Air-dry biochars were ground with mortar and pestle and sieved to achieve $149-$ to $850-\mu \mathrm{m}$ particle-size range. Samples were weighed to $200.0 \mathrm{mg}+/-5.0 \mathrm{mg}$ on weighing paper and then transferred to digestion or ashing vessels. Each paper was weighed following transfer to account for the sample retained on the paper. 


\section{Published Wet Digestion (PWD)}

After sample preparation as described previously, $5.0 \mathrm{~mL}$ of $69.0-70.0 \%$ trace-metal grade $\mathrm{HNO}_{3}$ (Mallinckrodt Baker, Inc., Phillipsburg, N.J.) was added to each digestion tube and allowed to sit overnight (Campbell and Plank 1998). Glass filter funnels (\#948027, Corning Life Sciences, Corning, N.Y.) were placed in the neck of the tubes during predigestion as a cover and to reflux acid fumes generated during digestion. Tubes were placed in a digestion block (Martin Machine Co., Ivesdale, Ill.), preheated to $120{ }^{\circ} \mathrm{C}$, and removed after $4 \mathrm{~h}$. Prior to dilution and filtering, the Corn300 digest appeared translucent dark yellow, Oak600 opaque dark brown, Poultry600 opaque brown, and ApCk transparent light yellow. Reflux funnels were removed after cooling, and $65 \mathrm{~mL}$ deionized water (DIW) was added to each digestion tube to achieve 5\% acid concentration. Contents were then vortexed and passed through qualitative cellulose filter paper (\#42, Whatman Inc., Piscataway, N.J.). Noticeable amount of solids were retained on the Corn300, Oak600, and Poultry600 filter papers.

\section{Published Dry-Ash Method (PDA)}

Samples were prepared as described previously and then placed in a cool muffle furnace (Fisher Isotemp Model 126, Thermo Fisher Scientific, Waltham, Mass.). A steel test tube rack, previously exposed to ashing conditions, was used to hold the digestion tubes upright. Samples were heated from ambient to $500{ }^{\circ} \mathrm{C}$ over $2 \mathrm{~h}$ and held at $500{ }^{\circ} \mathrm{C}$ for $8 \mathrm{~h}$ (Campbell and Plank 1998). The furnace was allowed to cool to $175^{\circ} \mathrm{C}$ before opening the door slightly. Samples were removed after internal temperature reached $30{ }^{\circ} \mathrm{C}$. At this point, Corn300 ash showed a gray color, Oak600 white, Poultry600 gray, and ApCk white. In accord with the method, $1.43 \mathrm{~mL} \mathrm{HNO}_{3}$ was added to each digestion tube and evaporated off at $120{ }^{\circ} \mathrm{C}$ in the digestion block. Samples were then ashed for an additional $8 \mathrm{~h}$. Following the second ashing, samples were solubilized as stated in the modified wet-digestion method and then filtered.

\section{Modified Wet Digestion (MWD)}

Samples were processed as described under PWD but were digested much longerfor $193 \mathrm{~h}$. At this point, Corn300 digests were clear yellow, Oak600 clear orange, Poultry600 clear yellow, and ApCk clear colorless. Hydrogen peroxide solution, 30-32\% v/v (Mallinckrodt Baker, Inc., Phillipsburg, N.J.) was added to the hot digests dropwise until bubbling dissipated, for a total of $30.0 \mathrm{~mL}$ per digestion tube. Reflux funnels were then removed, and samples were dried $15 \mathrm{~h}$ at $120{ }^{\circ} \mathrm{C}$. Following $\mathrm{H}_{2} \mathrm{O}_{2}$ addition, all samples were colorless except for Oak600, which retained a yellow color. An additional $2.0 \mathrm{~mL}$ $\mathrm{HNO}_{3}$ and $2.0 \mathrm{~mL} \mathrm{H}_{2} \mathrm{O}_{2}$ were added to all digestion tubes and processed for 5 additional hours to dryness. After cooling, $1.43 \mathrm{~mL} \mathrm{HNO}_{3}$ was added. Digests were then vortexed before adding $18.57 \mathrm{~mL}$ DIW to achieve 5\% acid concentration. Despite vortexing with concentrated acid, some ash adhered to the tube walls. This was overcome by placing digestion tubes in an ultrasonic water bath for $10 \mathrm{~min}$ (model 1200, Branson Ultrasonics Corp., Danbury, Conn.) before contents were filtered.

\section{Modified Dry Ash (MDA)}

To limit the exposure of samples to temperatures that could volatilize certain elements, while ensuring complete oxidation of recalcitrant $\mathrm{C}$ species, a wet-digestion step was 
substituted for the second ashing cycle. Samples were ashed as stated previously for one 8-h cycle. Following this, $5.0 \mathrm{~mL} \mathrm{HNO}_{3}$ was added to each vessel and processed at 120 ${ }^{\circ} \mathrm{C}$ on the digestion block until dryness was reached. Tubes were removed from the block and allowed to cool before adding $1.0 \mathrm{~mL} \mathrm{HNO}_{3}$ and $4.0 \mathrm{~mL} \mathrm{H}_{2} \mathrm{O}_{2}$. Samples were placed back into a preheated block, processed at $120^{\circ} \mathrm{C}$ to dryness, solubilized, and filtered as described previously.

\section{Perchloric Acid (PNW)}

Samples were predigested overnight with $1.0 \mathrm{~mL} \mathrm{HNO}_{3}$ prior to processing on a digestion block at $120{ }^{\circ} \mathrm{C}$ to dryness (Martin Machine Co., Ivesdale, Ill.). Following this, $1.0 \mathrm{~mL}$ of a 50/50 mixture of $\mathrm{HNO}_{3}$ and $70 \%$ ultra-trace-metal-grade $\mathrm{HClO}_{4}$ (GFS Chemicals, Powell, Ohio) was added and heated at $220{ }^{\circ} \mathrm{C}$ until dry. Ash was solubilized in $20.0 \mathrm{~mL}$ of $5 \% \mathrm{HNO}_{3}$ solution.

\section{Elemental Analysis of Digests}

After digestion, all samples were analyzed by an axially viewed ICP trace analyzer emission spectrometer (model ICAP 61E trace analyzer, Thermo Electron, Waltham, Mass.). The transfer optics had been replaced with a short depth-of-field transfer optics to reduce matrix effects.

\section{Statistical Analyses}

Analysis of variance (ANOVA) was carried out using JMP 9.0 (SAS, Cary, N.C.). Significant differences were calculated by post hoc tests across all methods for all materials using Tukey's HSD at $P<0.05$. Significant differences between MDA and EPA 3052 were calculated using Student's t-test at $P<0.05$. Comparison of standard deviations between methods may be problematic because of large differences in recovery. Methodological precision was therefore evaluated with percentage relative standard deviation (\%RSD), defined as

$$
\% \mathrm{RSD}=(\text { standard devaition/average }) \times 100
$$

\section{Results and Discussion}

\section{Elemental Recovery and Variability}

Digestion of Poultry600 demonstrated the greatest variability between methods compared to all other materials (Figure 1). Recoveries of P, K, S, calcium (Ca), magnesium (Mg), iron $(\mathrm{Fe})$, manganese $(\mathrm{Mn})$, and zinc (Zn) from Poultry600 were 10 to 100 times less using PWD and PDA than all other methods, presumably due to incomplete dissolution in the former and volatilization losses in the latter. There were no significant differences among MWD, MDA, or PNW for these elements from Poultry600.

The MDA method was either the most precise, or demonstrated relative standard deviation (\%RSD) within $3.7 \%$ of the most precise method, for recovery of $\mathrm{K}, \mathrm{S}, \mathrm{Ca}, \mathrm{Mg}$, $\mathrm{Mn}$, and Zn from Corn300 and Oak600 (Figures 2 and 3). Additionally, MDA was the most precise method for P and Fe from Corn300. The PNW method was either the most precise method or demonstrated a \% RSD within 3.8\% of the most precise method for recovery of $\mathrm{P}, \mathrm{K}, \mathrm{S}, \mathrm{Ca}, \mathrm{Mg}, \mathrm{Mn}$, and $\mathrm{Zn}$ from Poultry600. In comparison with EPA 

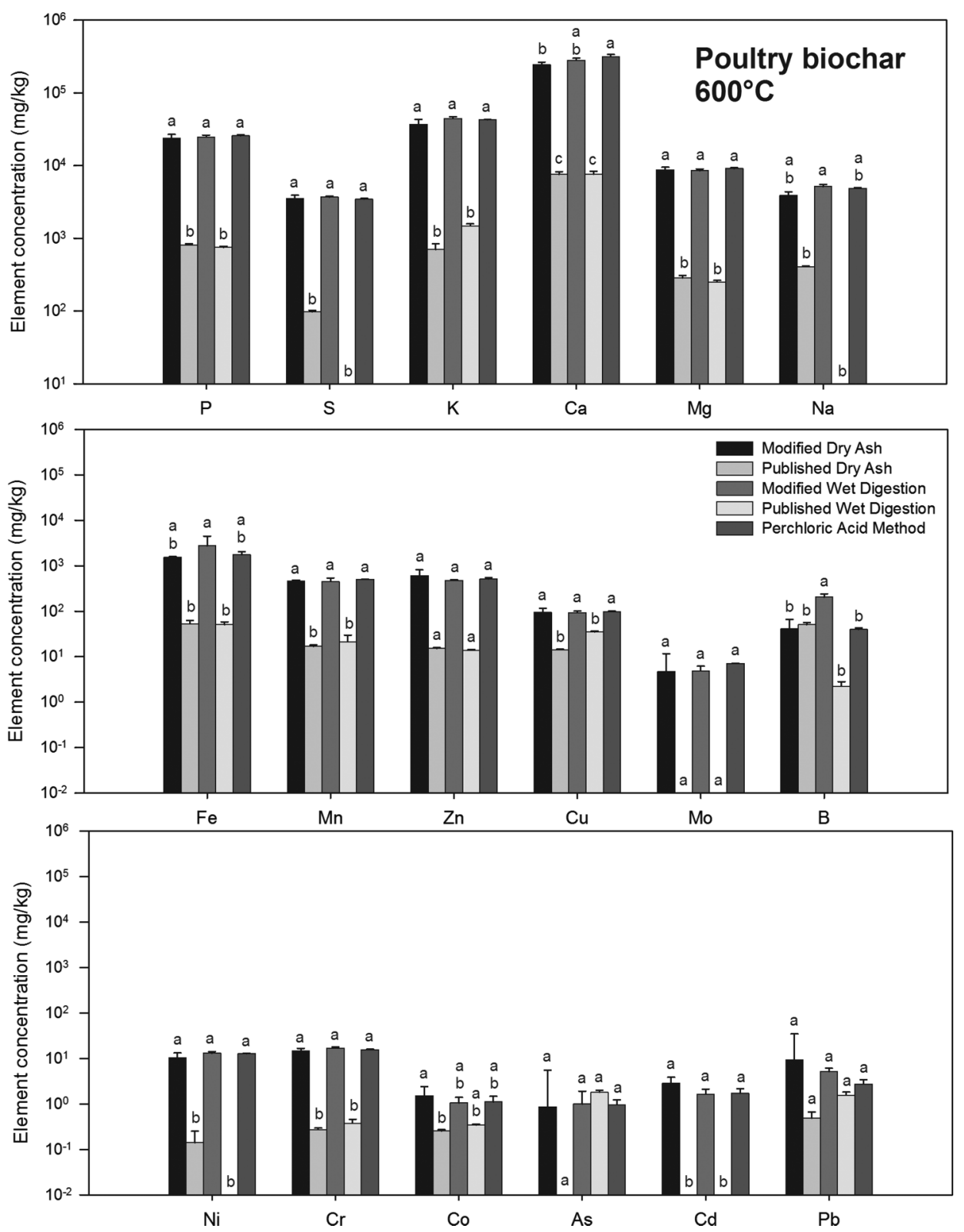

Figure 1. Total elemental contents of poultry biochar produced at $600{ }^{\circ} \mathrm{C}$ obtained by different digestion methods.

3052 microwave-assisted digest of the ApCk reference material (data not shown), MDA (Figure 4) yielded no significant differences for $\mathrm{P}, \mathrm{K}, \mathrm{Ca}, \mathrm{Mg}, \mathrm{Zn}$, and copper $(\mathrm{Cu})$, greater amounts of sodium (Na), and lesser amounts of boron (B), Fe, and Mn.

The PDA and MDA methods demonstrated greater return of $\mathrm{B}$ and $\mathrm{Na}$, suggesting thermally promoted contamination. Both B (Gestring and Soltanpour 1981) and Na leaching (Mizuike and Iino 1979) have been documented from borosilicate glass materials. Alkali-free analytical blanks would not correct for $\mathrm{Na}$ contamination, as alkali 

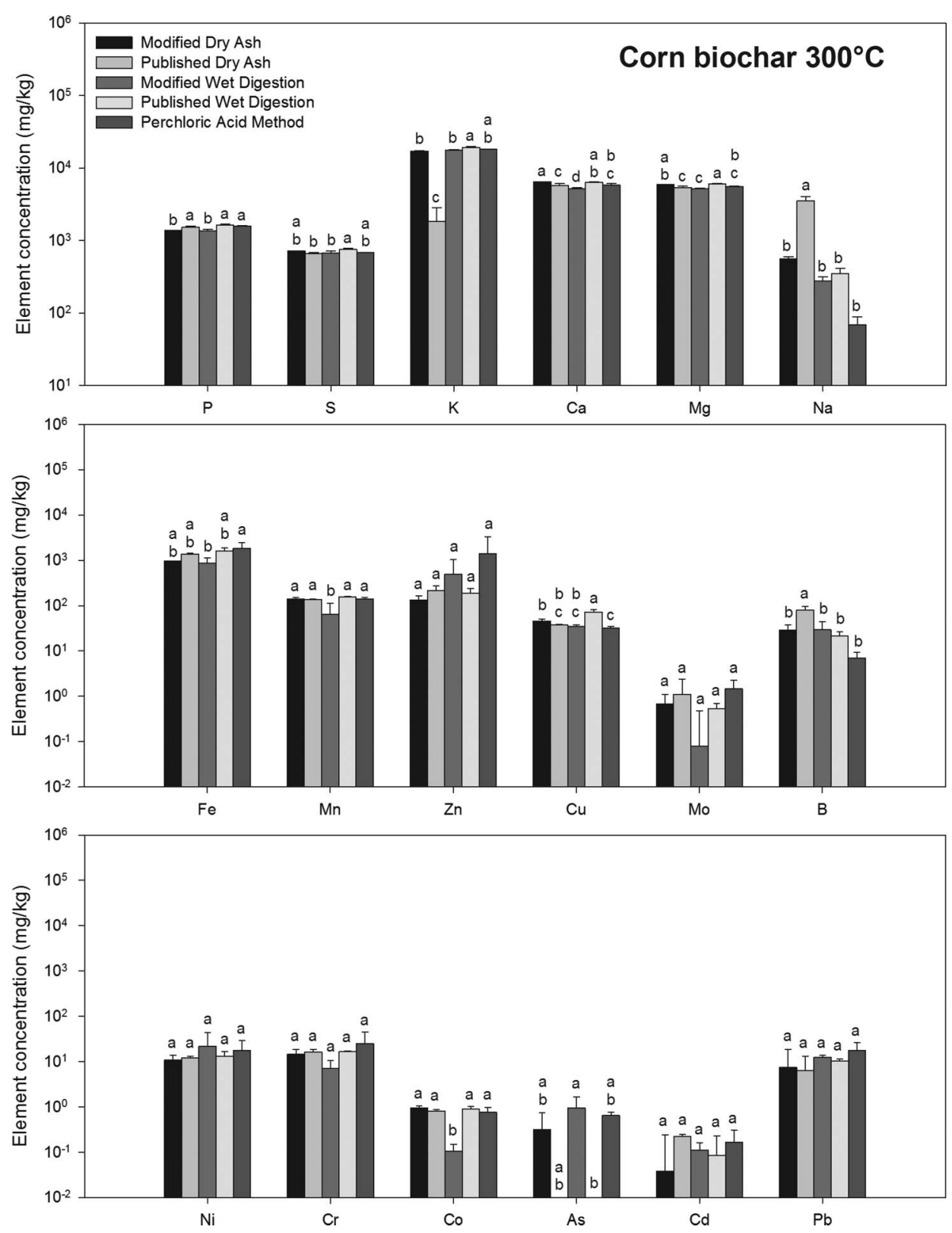

Figure 2. Total element contents of corn biochar produced at $300{ }^{\circ} \mathrm{C}$ obtained by different digestion methods.

interdiffusion processes in Pyrex glassware are partly concentration dependent (Morris et al. 1980).

\section{Decomposition}

The PWD for $4 \mathrm{~h}$ produced largely similar results for Corn300, Oak600, and ApCk when compared to a much more thorough MWD for $213 \mathrm{~h}$, despite the presence of solids in the 

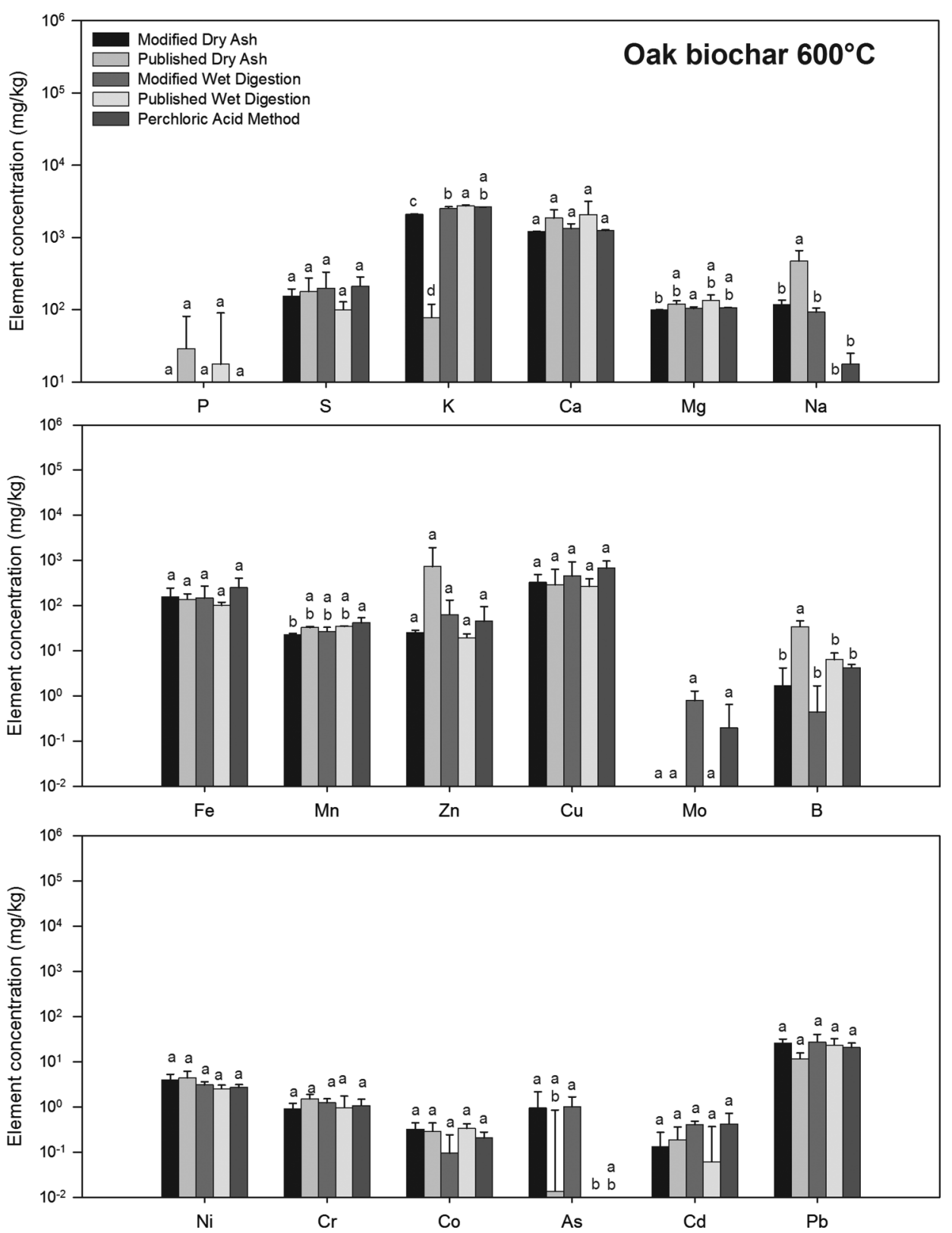

Figure 3. Total element contents of oak biochar produced at $600{ }^{\circ} \mathrm{C}$ obtained by different digestion methods.

former and the clear colorless appearance of the latter. Concerns over residual $\mathrm{C}$ in digests accumulating during preparation for ICP-AES seem unfounded, and the clear colorless endpoint as well as complete dissolution appears unnecessary for these materials. It is possible that mineral elements are readily leached from these biochars. However, PWD was inadequate to prepare Poultry600 for ICP. Biochar made from poultry litter has been shown to contain large amounts of mineral elements (Chan and Xu 2009). These may sinter under 

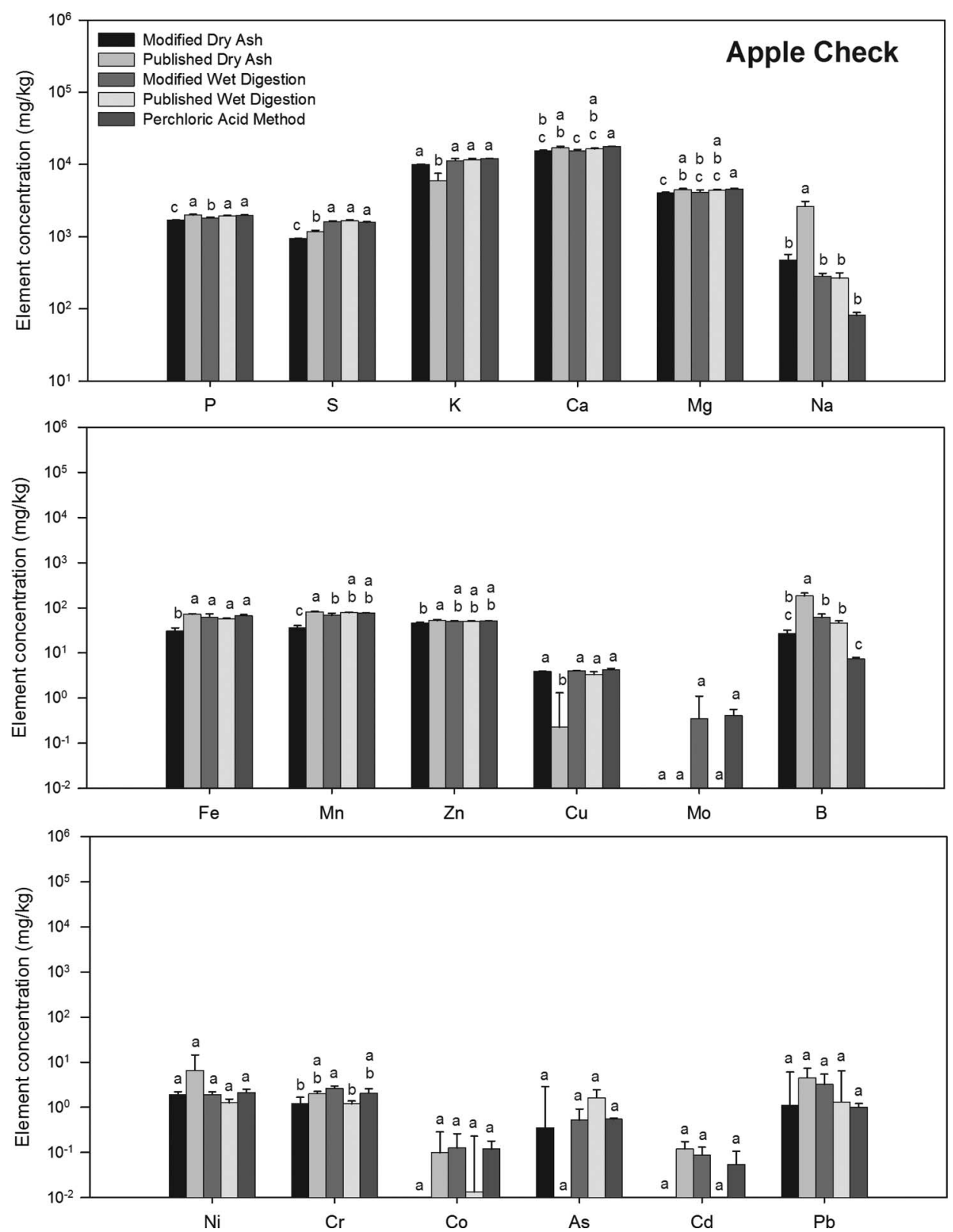

Figure 4. Total element contents of apple leaves obtained by different digestion methods.

high-temperature conditions (Risnes et al. 2003), thereby inhibiting dissolution. Whether some recalcitrant minerals are formed at $600{ }^{\circ} \mathrm{C}$ is not clear. Grinding samples to a fine powder would promote dissolution but could introduce error due to physical loss of sample via air currents or static charge.

The PDA and MDA methods accomplished the bulk of sample decomposition via thermal means. Therefore, dissolution of ash into the liquid matrix is more straightforward than 
that of biochar itself. The primary concern with these methods is loss due to volatilization rather than incomplete decomposition.

\section{Volatilization}

Compared with all other methods in this study, PDA returned significantly lower $\mathrm{K}$ for all materials except Poultry600 (Figures 1-4). In comparison with the PNW reference method, MDA demonstrated lower recoveries of $\mathrm{P}$ for Corn300 and ApCk, $\mathrm{K}$ for Oak600, and S for ApCk. Variability in data for As precludes detection of any significant difference between methods. Volatilization and contamination could be mitigated through oxygen enrichment of the muffle furnace environment to promote sample decomposition more quickly or at lower temperatures.

\section{Conclusions}

For all methods, precision improved as elemental concentrations increased. Trace-element quantification may require closed-vessel, microwave-assisted digestion methods to reduce losses due to volatilization (Sturgeon 2000). Contamination in trace analyses would be reduced by substituting vitreous silica or platinum for borosilicate labware (Zief 1980). The MDA method does, however, present a simple and accessible means to prepare samples for ICP with improved safety and a high degree of precision for the majority of plant macroand micronutrients.

\section{Acknowledgments}

We are grateful for the financial support by NYSERDA and the USDA Hatch program as well as the technical assistance and detailed analyses provided by Michael Rutzke and the Cornell Nutrient Analysis Laboratory for the standard material and accompanying microwave-digestion data.

\section{References}

Ali, M. W., S. C. Zoltai, and F. G. Radford. 1988. A comparison of dry and wet ashing methods for the elemental analysis of peat. Canadian Journal of Soil Science 68:443-447.

Amonette, J., and S. Joseph. 2009. Characteristics of biochar: Micro-chemical properties. In Biochar for environmental management, ed. J. Lehmann and S. Joseph, 35-54. London: Earthscan.

Campbell, C. R., and C. O. Plank. 1998. Preparation of plant tissue for laboratory analysis. In Handbook of reference methods for plant analysis, ed. Y. P. Kalra, 37-49. Boca Raton, Fl.: CRC Press.

Chan, K. Y., and Z. H. Xu. 2009. Biochar: Nutrient properties and their enhancement. In Biochar for environmental management, ed. J. Lehmann and S. Joseph, 67-84. London: Earthscan.

Cheng, C. H., J. Lehmann, J. E. Thies, and S. D. Burton. 2008. Stability of black carbon in soils across a climatic gradient. Journal of Geophysical Research 113:G02027.

Dean, J. A. 1999. Lange's handbook of chemistry, 15th ed. New York: McGraw-Hill.

Gestring, W. D., and P. N. Soltanpour. 1981. Evaluation of wet and dry digestion methods for boron determination in plant samples by ICP-AES. Communications in Soil Science and Plant Analysis 12:743-753.

Havlin, J. L., and P. N. Soltanpour. 1980. A nitric acid plant tissue digest method for use with inductively coupled plasma spectrometry. Communications in Soil Science and Plant Analysis 11:969-980. 
Hammes, K., M. W. I. Schmidt, R. J. Smernik, L. A. Currie, W. P. Ball, T. H. Nguyen, P. Louchouarn, S. Houel, Ö. Gustafsson., M. Elmquist, G. Cornelissen, J. O. Skjemstad, C. A. Masiello, J. Song, P. Peng, S. Mitra, J. C. Dunn, P. G. Hatcher, W. C. Hockaday, D. M. Smith, C. Hartkopf-Fröder, A. Böhmer, B. Lüer, B. J. Huebert, W. Amelung, S. Brodowski, L. Huang, W. Zhang, P. M. Gschwend, D. X. Flores-Cervantes, C. Largeau, J. N. Rouzaud, C. Rumpel, G. Guggenberger, K. Kaiser, A. Rodionov, F. J. Gonzalez-Vila, J. A. Gonzalez-Perez, J. M. de la Rosa, D. A. C. Manning, E. López-Capél, and L. Ding. 2007. Comparison of quantification methods to measure fire-derived (black/elemental) carbon in soils and sediments using reference materials from soil, water, sediment, and the atmosphere. Global Biogeochemical Cycles 21:GB3016.

Hsieh, Y. P. 2007. A novel multielemental scanning thermal analysis (MESTA) method for the identification and characterization of solid substances. Journal of AOAC International 90:54-59.

Huang, C. L., and E. E. Schulte. 1985. Digestion of plant tissue for analysis by ICP emission spectroscopy. Communications in Soil Science and Plant Analysis 16:943-958.

Jones, J. B. 2001. Laboratory guide for conducting soil tests and plant analysis. Boca Raton, Fl.: CRC Press.

Kuzyakov, Y., I. Subbotina, H. Chen, I. Bogomolova, and X. Xu. 2009. Black carbon decomposition and incorporation into microbial biomass estimated by ${ }^{14} \mathrm{C}$ labeling. Soil Biology and Biochemistry 41:210-219.

Lehmann, J. 2007. Bio-energy in the black. Frontiers in Ecology and the Environment 5:381-387.

Masiello, C. A. 2004. New directions in black carbon organic geochemistry. Marine Chemistry 92:201-213.

Mizuike, A., and A. Iino. 1979. Coating of borosilicate glass containers for preventing contamination in trace element analysis. Analytica Chimica Acta 111:251-256.

Morris, A. P., T. Dosdale, P. Knott, and N. R. Short. 1980. Cation exchange and interdiffusion in pyrex glass. Journal of Noncrystalline Solids 38:539-543.

Oliva, S. R., H. Raitio, and M. D. Mingorance. 2003. Comparison of two wet digestion procedures for multielement analysis of plant samples. Communications in Soil Science and Plant Analysis 34:2913-2923.

Risnes, H., J. Fjellerup, U. Henriksen, A. Moilanen, P. Norby, K. Papadakis, D. Posselt, and L. H. Sørensen. 2003. Calcium addition in straw gasification. Fuel 82:5641-651.

Sturgeon, R. E. 2000. Current practice and recent developments in analytical methodology for trace element analysis of soils, plants, and water. Communications in Soil Science and Plant Analysis 31:1479-1512.

Tartarelli, R., M. Giorgini, P. Ghetti, and R. Belli. 1987. DTG combustion behavior of charcoals. Fuel 66:1737-1738.

Wasilewska, M., W. Goessler, M. Zischka, B. Maichin, and G. Knapp. 2002. Efficiency of oxidation in wet digestion procedures and influence from the residual organic carbon content on selected techniques for determination of trace elements. Journal of Analytical Atomic Spectroscopy 17:1121-1125.

Zief, M. 1980. Contamination control in trace element analysis (Special Technical Publication 708), 66-77. Philadelphia: ASTM. 